\title{
Who Participates in Popular Feasts and Festivals? An Empirical Approach from Cultural Economics Applied to the Carnival of Barranquilla (Colombia)
}

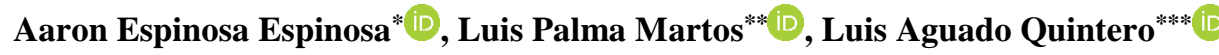

\begin{abstract}
The empirical analysis of individual participation in local and popular feasts and festivals is a field little explored by cultural economists. This article proposes a methodological scheme to analyse the profile of the participants in local and popular feasts and carnivals, allowing the establishment of a taxonomy that captures the heterogeneity of the participants replicable to other festivities and carnivals around the world. Similarly, participation equations that allow the analysis of the influence of context variables on individual decisions to participate in these types of events are estimated. For this, the Carnival of Barranquilla, the largest and most representative popular celebration in Colombia and declared by UNESCO as Intangible Cultural Heritage of Humanity, is used as a case study. The data were obtained from the Citizen Perception Survey of the Barranquilla Cómo Vamos programme, which evaluates the quality of life and the fulfilment of development plans in that city, and an empirical strategy is employed consisting of the estimation of a probit discrete choice model, which allows modelling the individual decisions of a time-intensive good, such as a carnival, with a strong influence of traditional variables, such as cultural capital and the availability of leisure time, and other context variables: location of people in the territory, stratification and poverty. The different profiles found offer information on the different strategies that can be implemented from public policy to stimulate greater participation by the population in popular festivities and festivals.
\end{abstract}

Keywords: Carnival of Barranquilla; cultural participation; intangible heritage; probit models; Colombia.

JEL classification: C25; C26; R21; Z10; Z11.

\section{INTRODUCTION}

The participation of the population in popular feasts and festivals is one of the least studied fields by cultural economists (Palma, Palma, \& Aguado, 2013). This scarcity is more noticeable if one considers the degree of heterogeneity of those who appropriate these

\footnotetext{
" Instituto de Estudios en Desarrollo, Economía y Sostenibilidad (IDEEAS), Laboratorio de Investigación e Innovación en Cultura y Desarrollo (L+iD), Universidad Tecnológica de Bolívar, Colombia; e-mail: aespinosa@utb.edu.co (corresponding author).

*** Departamento de Economía e Historia Económica de la Universidad de Sevilla, Spain; e-mail: lpalma@us.es.

**** Departamento de Economía, Pontificia Universidad Javeriana, Colombia; e-mail: lfaguado@javerianacali.edu.co.
} 
celebrations. The size of the population and the diversity of heritage expressions involved are some of the reasons why the knowledge base on this subject should be expanded in regions such as Latin America and countries such as Colombia, where approximately 3,000 celebrations of this nature are held each year (González Pérez, 2018).

In Colombia, the Carnival of Barranquilla stands out for its magnitude, roots and cultural richness, recognized as the most representative popular festival of this country and one of the most traditional festivals in Latin America (J. Abello, 2020; Salcedo, 2002). From the point of view of participation, in recent decades, there has been a discussion about the need to democratize and expand the access of the local population to this feast declared Intangible Cultural Heritage of Humanity in 2003. In more recent years, its Special Safeguarding Plan (Plan Especial de Salvaguardia - PES) has stated that it faces a set of risks "that limit the right of access of people to knowledge, use and enjoyment" and others associated with the practices of the manifestation and intergenerational transmission of knowledge (Observatorio del Caribe Colombiano, 2015, pp. 45-47).

From an economic point of view, this popular celebration is characterized by being a time-intensive good, which requires other resources and strong social interaction to be consumed (Espinosa, Palma, \& Aguado, 2020). In this popular feast, more than 30 thousand doers, bearers and other actors participate each year, animating the celebration with individual and collective performances: comparsas, folkloric, musical and dance groups, in addition to theatrical performances and other street performing arts. During the four days of its celebration, a proportion close to $50 \%$ of the local population gathers. The participants are part of a diverse social and cultural fabric, a form of expression of the intangible cultural heritage associated with the idiosyncrasy and past of a territory, reflected in the mixing of Amerindian, European and African cultures (M. Abello, Buelvas, \& Caballero, 2005).

Therefore, this study aims to characterize and analyse the factors that influence the individual decision to participate in the Carnival of Barranquilla, taking into account its different forms of appropriation. Due to the level of detail proposed, this analysis is called the anatomy of the participant, that is, a detailed study according to the frequency and type of participation. To carry this out, the information base of the Citizen Perception Survey (CPS) of the Barranquilla Cómo Vamos (BCV) programme, is used, a citizen control programme that monitors local development plans, and an empirical strategy is applied to evaluate the role of a set of traditional factors and others little used in the literature (Aguado \& Palma, 2015; Espinosa $\&$ Palma, 2019). The latter are aimed at understanding the role of the local context in the attendance and appropriation of this popular feast originating in the $19^{\text {th }}$ century.

There are several reasons for proposing the following study. The main one is the potential contribution of the cultural economics to the analysis - not performed until now of a cultural asset such as carnival, which combines tangible and intangible characteristics, from the perspective of participation. Although the Carnival of Barranquilla has been the subject of various analyses from other social sciences for decades (M. Abello et al., 2005; Buelvas, 2005, 2011; Carbó, 1993; Espinosa \& Seni, 2019; Gilard, 1999; Mariano \& Endere, 2017; Rey Sinning, 2004), its economic dimension has not only been little studied but also reduced to the mere tangible contribution: its contribution to employment, to income generation and to the increase in the local production of goods and services (Cámara de Comercio de Barranquilla \& Carnaval de Barranquilla SAS, 2017).

The study contributes to the literature because it is the first study proposed from the cultural economics that analyses popular festivities in Colombia and Latin America from a 
demand perspective, expanding the existing knowledge about cultural consumption in this country and the region. To date, this country has studied participation through performing arts, attending museums and libraries, reading books and newspapers, consumption of recorded music, attending movies and historical sites and monumental heritage (Aguado, 2011; Andrade, 2016; Bermúdez, Medina, \& Aguado, 2016; Espinosa \& Palma, 2019; Espinosa \& Toro, 2016; Palma, Aguado, \& Osorio, 2014).

In the section that follows this introduction, a review of the relevant literature on cultural participation in general and in popular festivities from the perspective of the cultural economics is presented. In the third section, the methodology and data used to adequately treat participation in the carnival are explained. In the fourth section, the results of the research are presented, in particular, in a descriptive and empirical way the anatomy of the participant, according to the frequency (occasional, frequent and regulars) and the type of participation (pre-carnival events, parade attendants, members of comparsas and folk groups, attending concerts and dances, and booths, street parties and popular activities, among others). The fifth section presents some reflections on the actions that can contribute to expanding participation in the carnival.

\section{LITERATURE REVIEW}

\subsection{Cultural participation: conceptual references and economic literature}

In this work, reflections on participation aimed at understanding why people choose cultural activities, particularly popular festivities and festivals, are collected, not only for utilitarian purposes but also as a symbolic vehicle (Throsby, 2006, p. 7). Alternative activities, which also require the use of time and resources, such as those that involve responsibilities such as working and studying in different areas and forms, restrict voluntary action to participate and condition the structure of individual preferences.

Becker (1965) and later Stigler and Becker (1977) show how the consumption of goods and services of this nature produces cultural experiences. These goods do not represent by themselves the satisfiers of cultural needs but are combined with time and resources in the hypothetical form of an individual production function. A key role in enjoyment is played by cultural capital, defined by Throsby as a good that embodies, stocks or gives rise to a cultural value in addition to the economic value it may possess; this capital can be evaluated in quantitative and qualitative terms against a variety of attributes such as aesthetic quality, spiritual meaning, social function, symbolic meaning and historical importance, among others (Throsby, 2003, p. 167).

In the formation of cultural capital, general education and artistic education (as a specific education) intervene directly and the transmission of taste and passion for different cultural expressions from parents to children intervenes indirectly. In our case study, learning has a significant effect on participation in popular festivities, which by their nature represent the "culture of a group", inherited traditions, values and beliefs.

The set of factors that condition the decision to participate in cultural activities has been studied in recent years for regions and countries (Ateca-Amestoy, 2010; Casarin \& Moretti, 2011; Falk \& Katz-Gerro, 2016) and for a large group of activities such as the performing arts (Ateca-Amestoy, 2009; Borgonovi, 2004; Mauri \& Wolf, 2021; Seaman, 2006), the demand for books and newspapers and reading habits (Fernández-Blanco \& Prieto-Rodríguez, 2009; 
Ringstad \& Loyland, 2006; Villarroya \& Escardibul, 2010), consumption of folk music (Montoro-Pons, Cuadrado-Garcia, \& Casasus-Estelles, 2013) and attending festivals and popular festivities (Heredia-Carroza, Palma, \& Marín, 2020; Palma et al., 2013), among others.

In retrospect, cultural participation gains strength in the concept of participation gap proposed more than fifty years ago by Baumol and Bowen (1966) to analyse consumption in the performing arts. It is possible to explain this gap based on the taste for cultural goods and services, which, according to Throsby (2001) and McCain (2003), is cumulative and increases with time and with greater exposure to art.

Taste comes from the experiences of previous cultural consumption through mechanisms of rational addiction and learning through consumption. Rational addiction thus depends, according to Stigler and Becker (1977) and Becker and Murphy (1988), on the time spent on cultural consumption and on accumulated human capital. In the words of the latter authors, a good is potentially addictive if increases in past consumption increase current consumption. At the same time, this heritage comes from past cultural experience and investment in cultural education, again generating a process of rational addiction that projects the tastes of those who participate in cultural life.

In addition to the aforementioned factors, this study is based on the hypothesis that there is a set of structural factors that affect cultural participation. According to Aguado and Palma (2015), they are factors, in addition to those proposed by Stigler and Becker (1977), that condition and modify the social and economic valuation of cultural activities.

However, the vision of Aguado and Palma (2015) requires, on the one hand, applying it to the context of the cities of developing countries and the practice of time-intensive activities such as popular festivities, and on the other hand, empirical treatment through variables that adequately capture the role of these contexts that are, by nature, contrasting, and represent a network of relationships that must be documented. In fact, for the Carnival of Barranquilla, there are few references in the empirical literature.

Internationally, there are few studies, and in Colombia, there are no studies on attendance at popular festivities. The studies by Daneshvary, Schwer, and Rickman (1993) on rodeos in the USA and Palma et al. (2013) on the Spring Fiestas in Seville stand out. Due to its similarity, this last work presents findings that allow defining its celebrations as a prototype of a complex cultural asset based on both intangible and tangible cultural heritage. Aspects linked to knowledge, institutional links and experiences (which enrich cultural memory) are determinants of participation in these festivities; however, these authors find that, against the evidence of participation studies on other cultural assets, the traditional socioeconomic variables such as general education or income are not significant.

Unlike the study by Palma et al. (2013), in the analysis of the Carnival of Barranquilla, there is an information base that allows to understand in detail participation in this popular celebration according to the intensity and type of actors involved in the celebration. In this way, the research contributes to the literature on cultural economics by constructing a broader and more detailed anatomy of the carnival. However, they share analytical aspects in common: they deal with time-intensive activities in consumption, they are defined as a leisure good in the sense already explained by Becker (1965), and they are consumed outside the home, so they require prior knowledge about the good and an active social interaction. 


\subsection{Studies in Colombia: cultural participation and carnival}

In Colombia, studies on cultural participation that are addressed from the cultural economics have gained importance in recent years. The most recent examines the evolution of cultural participation in Colombia between 2008 and 2015 in its five main cities in a wide range of activities, such as cinema, theatre, book reading, popular festivities (other than carnivals), attendance to library and monuments, among others (Espinosa \& Palma, 2019). According to Espinosa and Palma (2019), the negative effects of structural factors such as poverty (objective and subjective), economic and educational inequalities, socioeconomic status, insecurity and the low endowment of public goods (habitat) have been compensated by social capital (community participation), cultural capital (education) and cultural policies (weak impact) and cultural governance (greater effect).

Regarding carnival, studies have been proposed mainly from disciplines such as anthropology (M. Abello et al., 2005; de Friedemann, 1984; Lizcano \& Gonzalez, 2007; Mariano \& Endere, 2017), sociology (González, 2006; Rey Sinning, 2004; Reyes, 2011), communication and musicology (Carbó, 1993; Espinosa \& Seni, 2019; Ochoa, 2015), among others.

In its genesis, the Carnival of Barranquilla is considered a republican festival with origin in the religious and pagan celebrations of the Colony, in particular, in those of the neighbouring city of Cartagena de Indias. Among these are the festivities of January 20 (San Sebastián Day), the festivity of Our Lady of Candelaria (patron saint of Cartagena, on February 2) and the famous festive extensions that connected with Lent (Buelvas, 1993). An essential festive institution in the celebrations during the Colony was the town councils of African tradition, which initially converged in the festivities of La Candelaria and in the carnivals (Gutiérrez, 2009; Muñoz, 2007; Ruz \& Abello, 2016).

In its constitution and development, the Carnival of Barranquilla also shares a repertoire of manifestations of the different cultures and peoples of America, Europe and Africa (M. Abello et al., 2005). In addition to showing worldviews, carnivals today involve processes of expression, interpretation and creation that occur in the public environment (parades, concerts, booths, exhibitions, etc.) or private environments (club parties and meetings), actively (in comparsas, musical groups, street art) or passively (as spectators), processes that show the transition from a collective memory of tradition to a contemporary one (Table no. 1).

Table no. 1 - Attributes of the Carnival of Barranquilla

\begin{tabular}{|c|c|c|}
\hline & \multicolumn{2}{|c|}{ Carnival of Barranquilla } \\
\hline & Free & Mixed and paid \\
\hline Events & $\begin{array}{l}\text { - Joselito Carnaval/* } \\
\text { - } \quad \text { Festival de Danzas de Relación/* } \\
\text { - } \quad \text { Night of Comparsas/* } \\
\text { - } \quad \text { Dance and Cumbia Parties */ }\end{array}$ & $\begin{array}{l}\text { - } \text { Lectura del Bando/** } \\
\text { - } \text { Festival of Orchestras/** } \\
\text { - } \text { Coronation of the carnival queen/*** } \\
\text { - } \text { Concerts/*** } \\
\text { - Street parties (neighbourhoods)/**** } \\
\text { - } \quad \text { Baila la Calle } * * *\end{array}$ \\
\hline Parades & $\begin{array}{l}\text { - } \quad \text { Carnaval de la } 44 / * \\
\text { - } \quad \text { La Calle } 84 * / \\
\text { - } \quad \text { Desfile de la } 17 / *\end{array}$ & $\begin{array}{l}\text { - } \text { Gran Parada de Tradición/** } \\
\text { - Gran Parada de Comparsas/** } \\
\text { - } \text { Batalla de Flores/** } \\
\text { - LGBT Community Parade/** } \\
\text { - Children's Carnival/** } \\
\text { - } \text { La Guacherna/** }\end{array}$ \\
\hline
\end{tabular}




\begin{tabular}{|c|c|}
\hline & Carnival of Barranquilla \\
\hline Related events & $\begin{array}{ll}\text { - Exhibitions and other museum } & \text { - Carnaval de las Artes**/ } \\
\text { activities } * & \text { - Private concerts in hotels and clubs } * * * \\
\text { - La Noche del Río* } & \text { - Encuentros de colonias*** } \\
\text { - La Noche de Tambó* } & \\
\text { - Carnavaladas* } & \\
\end{array}$ \\
\hline $\begin{array}{l}\text { Traditional } \\
\text { expressions }\end{array}$ & $\begin{array}{l}\text { Dances: Cumbia, Garabato, Congo, Mapalé, Baile Negro and Son de Negro. } \\
\text { - Danzas de relación y especiales: Paloteo, Coyongos, Goleros or Gallinazos, Caimán } \\
\text { and Las Pilanderas, Danza de Diablos, del Gusano, de las Farotas and de Indios. } \\
\text { - Music: The groups of millos or bagpipes (cumbias, bullerengues, or Mapalés); wind } \\
\text { bands (porros and fandangos); parrandas vallenatas (aires vallenatos); bullerengue. }\end{array}$ \\
\hline $\begin{array}{l}\text { Infrastructures } \\
\text { and cultural } \\
\text { access }\end{array}$ & $\begin{array}{l}\text { - Casa del Carnaval } \\
\text { - Sala del Carnaval "Elsa Caridi” } \\
\text { - } \text { La Tienda del Carnaval } \\
\text { - Cumbiódromo (Vía 40) } \\
\text { - Paseo Buseo El Torito } \\
\text { - } \text { Barrio El Prado } \\
\text { - Edificio de la Aduana } \\
\text { - Plaza de la Paz } \\
\text { - } \text { Sports infrastructure (Romelio Martínez Stadium) } \\
\end{array}$ \\
\hline Credentials & $\begin{array}{l}\text { - National Cultural Heritage [Law 706/November 26, } 2001 \text { of the Congress of the } \\
\text { Republic]. See: http://www.secretariasenado.gov.co/senado/basedoc/ley_0706_2001.html } \\
\text { - Masterpiece of the Oral and Intangible Heritage of Humanity. [November 7/2003, } \\
\text { UNESCO]. Included in the Representative List of Cultural Heritage of Humanity [2008, } \\
\text { UNESCO] See: https://ich.unesco.org/es/RL/el-carnaval-de-barranquilla-00051 } \\
\text { - Third place in the competition to choose the cultural symbol of Colombia (organized } \\
\text { by the magazine Semana, Caracol TV, Ministry of Culture and Colombia es Pasión) } \\
\text { (programme of the Ministry of Commerce, Industry and Tourism). }\end{array}$ \\
\hline Duration & $\begin{array}{l}\text { Duration: four days, counted from the Saturday of carnival. } \\
\text { keys to the city by the mayor to the Carnival queen and Lectura del Bando by the queen. It } \\
\text { ends on the Saturday of Carnival. }\end{array}$ \\
\hline
\end{tabular}

Note: /Street event, in a public square. * Free events. ** Mixed, subject to availability of free spaces in noncommercialized areas. *** Access completely paid.

Source: Own elaboration based on Carnaval de Barranquilla SAS, M. Abello et al. (2005), Buelvas (1993), https://www.barranquilla.gov.co

In the carnivals, activities and ways of life are also represented at the individual level (a costume or a performance), group (a comparsa or a dance) or collectively (La Guacherna, la Muerte de Joselito, among others). Many activities go through the sieve of the economy and the market, which are carried out in infrastructures built to guarantee a minimum of free attendance (Table no. 1). After the marked decline that it suffered between 1970 and 1980, at the end of the $20^{\text {th }}$ century, its management model was changed, from a public one where the interests of the political sector predominated to a public-private one that manages the celebration with efficiency criteria and democratization of access (González, 2006).

Although with this new turn, the celebration increased in magnitude and dynamism, the commercialization of the most representative and crowded public events was accentuated (Table no. 1), and more space was given to private financing. These changes have hindered the participation of wide swaths of the local population and have placed under scrutiny the adequate transmission of symbolic content and traditional cultural references, identifying it 
Scientific Annals of Economics and Business, 2021, Volume 68, Special Issue, pp. 79-103

as one of the main risks to ensure its sustainability (J. Abello, 2020; Observatorio del Caribe Colombiano, 2015; Rey Sinning, 2004).

With the revitalization achieved in the nineties with the change in its management, the carnival has become an important mobilizer of economic resources. Some US5 million are invested in its organization per year, and in 2017, more than 35,000 artists participated; 9,700 musicians and 1,864,000 attendees were counted ( $31 \%$ of the attendance at the Rio Carnival, of 5,892,700 persons on the same year). Since 2016, it has a project bank that has allocated public resources to creators and bearers for a total amount of US \$4.5 million.

In addition to the participants in the parades and activities, a network of traditional mask creators, fashion and costume designers, music creators and gastronomy promoters converge in the carnival, which is an example of the growing importance of cultural and creative industries. The total estimated impact on the local economy during the four days has been estimated at approximately US \$16.2 million (Cámara de Comercio de Barranquilla \& Carnaval de Barranquilla SAS, 2017).

\section{METHODOLOGY AND DATA}

\subsection{Data}

For this research, the Citizen Perception Survey (CPS) of the Barranquilla Cómo Vamos programme is available, with which different profiles of the attendees can be characterized and empirically evaluated for the role of the factors associated with participation in the Carnival of Barranquilla. The CPS, which has been applied since 2008, aims to inform and evaluate changes in the quality of life based on compliance with the development plans of the city. It is, therefore, an instrument for monitoring and managing public policies. The CPS is applied annually to approximately 1,200 households in the city.

In this work, representative households of Barranquilla are analysed according to different criteria (locality, strata, among others) ${ }^{1}$. Special attention is given to 2011 because in this year, the information on participation is more detailed than the rest of the period. As shown in Table no. 2, this year, there is information on active participants (members of comparsas and folkloric groups, households that organize parties, among others) and passive participants (spectators at parades, attendees at concerts and dances, booths, street parties and popular activities, among others).

There is also enough information to analyse the frequency of participation, a key issue in regard to understanding the nature of the decisions of individuals. In fact, the study of three types of participants is proposed: occasional, frequent and regulars, following what has been proposed in other analyses on Colombia (Aguado, 2011; Andrade, 2016). The analysis of both criteria allows to complete the analysis of the anatomy of the participant and to estimate the same determinants associated (both traditional and structural) with the decision to become involved in the carnestolendas.

The traditional explanatory variables are those that have been used frequently in the theoretical and empirical literature on the determinants of cultural participation. These variables are educational level (used as an approximation of cultural capital), income and time availability (Ateca-Amestoy, 2008). Although the survey asks for income, they are not available for the year analysed; therefore, a subjective variable on economic situation is used. 
Table no. 2 - Study variables (definition, characteristics and typology)

\begin{tabular}{|c|c|c|c|c|}
\hline Variable & Definition & Type & Description & $\begin{array}{c}\text { Factor/ } \\
\text { variable }\end{array}$ \\
\hline $\begin{array}{l}\text { Participation in } \\
\text { carnival }\end{array}$ & $\begin{array}{l}\text { During the } 2011 \text { Carnival, in } \\
\text { which of these activities did you } \\
\text { participate? } \\
\text { 1. Watching the parades } \\
\text { 2. Parading; in comparsas and } \\
\text { folk groups } \\
\text { 3. Concerts and dances } \\
\text { 4. Booths, street parties and } \\
\text { popular activities } \\
\text { 5. Cultural activities } \\
\text { 6. Parties organized by you, by } \\
\text { acquaintances or by friends } \\
\text { 7. None }\end{array}$ & $\begin{array}{l}\text { Dummy } \\
\text { (D) }\end{array}$ & $\begin{array}{l}1 \text { = Participates in some of these } \\
\text { activities; } 0=\text { Does not } \\
\text { participate in any } \\
\text { Occasional: participate in } 1-2 \\
\text { activities. } \\
\text { Frequent: } 3-4 \text { activities. } \\
\text { Regulars: } 5 \text { and } 6 \text { activities. }\end{array}$ & Dependent \\
\hline Gender & Gender of the head of household & $\mathrm{D}$ & $1=$ Male $; 0=$ Female & Traditional \\
\hline Age & $\begin{array}{l}\text { Age range of those who } \\
\text { participate in carnival activities }\end{array}$ & $\begin{array}{l}\text { Ordered } \\
\text { (O) }\end{array}$ & $\begin{array}{l}1=18 \text { to } 25 \text { years; } 2=26 \text { to } 35 \\
\text { years; } 3=36 \text { to } 45 \text { years; } 4=46 \\
\text { to } 55 \text { years and } 6=\text { Older than } 55 \\
\text { years. }\end{array}$ & Traditional \\
\hline Leisure time & Do you currently...? & $\mathrm{O}$ & $\begin{array}{l}1=\text { Retirees; } 2=\text { Work outside } \\
\text { the home; } 3=\text { Work at home; } 4= \\
\text { Study; } 5=\text { Work and study; and } \\
6=\text { Head of household. }\end{array}$ & Traditional \\
\hline Cultural capital & Educational level & $\mathrm{O}$ & $\begin{array}{l}1=\text { None; } 2=\text { Primary } \\
\text { education; } 3=\text { High school; } 4= \\
\text { Tertiary education (university } \\
\text { undergraduate + postgraduate: } \\
\text { specialization, masters or } \\
\text { doctorate). }\end{array}$ & Traditional \\
\hline $\begin{array}{l}\text { Children } \\
\text { attending } \\
\text { private school } \\
\text { (ref.: attendance } \\
\text { at public } \\
\text { schools) }\end{array}$ & $\begin{array}{l}\text { In this household, are there } \\
\text { children or young people between } \\
5 \text { and } 17 \text { years old who attend a } \\
\text { public institution and/or a private } \\
\text { institution, or } \\
\text { are there children, but they do not } \\
\text { attend any type of educational } \\
\text { establishment? Those who have } \\
\text { already finished high school are } \\
\text { not included. }\end{array}$ & $\mathrm{D}$ & $\begin{array}{l}1=\text { attends private school } \\
0=\text { attends public school }\end{array}$ & Structural \\
\hline $\begin{array}{l}\text { Income per } \\
\text { inhabitant }\end{array}$ & $\begin{array}{l}\text { Per capita income of the } \\
\text { expenditure unit (household) of } \\
\text { Barranquilla }\end{array}$ & $\mathrm{C}$ & $\begin{array}{l}\text { In constant Colombian pesos of } \\
\text { the year } 2015 \text {. }\end{array}$ & Traditional \\
\hline Income & Household income & $\mathrm{O}$ & $\begin{array}{l}\text { In current pesos. } 1 \text { : Less than } 1 \\
\text { minimum wage; } 2 \text { : Between } 1 \\
\text { and } 3 \mathrm{MW} ; 3 \text { : Between } 3 \text { and } 4 \text {; } \\
4:>4 \mathrm{MW} \text {. }\end{array}$ & Traditional \\
\hline $\begin{array}{l}\text { Economic } \\
\text { situation }\end{array}$ & $\begin{array}{l}\text { Rate the economic situation of } \\
\text { the household (proxy of income) }\end{array}$ & $\mathrm{O}$ & $\begin{array}{l}\text { 1: Has worsened; } 2: \text { Remains } \\
\text { the same; } 3 \text { : Has improved. }\end{array}$ & Traditional \\
\hline $\begin{array}{l}\text { Objective } \\
\text { poverty }\end{array}$ & $\begin{array}{l}\text { Did you stop consuming any of } \\
\text { the three meals in the last week? }\end{array}$ & $\mathrm{D}$ & $1=\mathrm{Yes} ; 0=\mathrm{No}$ & Structural \\
\hline
\end{tabular}




\begin{tabular}{|c|c|c|c|c|}
\hline Variable & Definition & Type & Description & $\begin{array}{c}\text { Factor/ } \\
\text { variable }\end{array}$ \\
\hline $\begin{array}{l}\text { Socioeconomic } \\
\text { status }\end{array}$ & Socioeconomic stratification & $\mathrm{O}$ & $\begin{array}{l}\text { Low level = strata } 1 \text { and 2; } \\
\text { Medium: strata } 3 \text { and 4; High: } 5 \\
\text { and } 6\end{array}$ & Structural \\
\hline $\begin{array}{l}\text { Security in the } \\
\text { city }\end{array}$ & $\begin{array}{l}\text { Measures the degree of security } \\
\text { in the city. }\end{array}$ & $\mathrm{O}$ & $\begin{array}{l}\text { Homicide rate per } 100 \text { thousand } \\
\text { inhabitants. }\end{array}$ & Structural \\
\hline Social capital & $\begin{array}{l}\text { Belongs to a community-based } \\
\text { organization other than cultural } \\
\text { (civic, professional, sports, } \\
\text { religious, social clubs, among } \\
\text { others.) }\end{array}$ & $\mathrm{D}$ & $1=$ Yes $; 0=$ No & Structural \\
\hline Fixed effects & $\begin{array}{l}\text { Dummy by locality } \\
\text { (Metropolitan, North-Central } \\
\text { Historical, Riomar, Southwestern } \\
\text { and Southeastern). }\end{array}$ & $\mathrm{D}$ & $\begin{array}{l}1=\text { Yes (reference locality) } \\
0=\text { Rest of localities }\end{array}$ & Structural \\
\hline
\end{tabular}

Finally, the context variables aim to capture the effects of the structural factors of participation (Aguado \& Palma, 2015), which are those that condition the social and economic evaluation of the participation of individuals. This group of variables includes socioeconomic status, measured through social stratification ${ }^{2}$, objective and subjective poverty, security, social capital and fixed effects explained by the location of the population.

\subsection{Empirical strategy}

As explained in the previous section, the proposed analysis is based on rational expectations models that assume cultural participation as a rational addiction; this is the result, in turn, of the experience and investment accumulated by individuals in the formation of taste, a process that occurs over time (Lévy-Garboua \& Montmarquette, 1996; Palma et al., 2013; Stigler \& Becker, 1977).

To give a methodological body to this notion, it is started from a behavioural model in which people choose to participate or not participate in carnival activities. Each member of the household selects one or several activities that maximize their satisfaction, adjusting their decision to the existence of revealed preferences of the consumers of these goods and services. The discrete choice utility model is used to describe this welfare-maximizing behaviour (McFadden, 1973). This model explains that each person who makes up the household chooses between several options - in our case cultural, and within these, the carnival - the one or those that report the greatest satisfaction.

Due to the nature of the decision (to go to the carnival or not) at one point in time, a probit-type binary choice model was chosen, where the errors capture the heterogeneity component in the preferences of the households (Equation 1). Under the assumption that the cumulative distribution function of the stochastic error term follows a normal distribution (Verbeek \& Vella, 2005), the parameters of interest are estimated under the maximum likelihood procedure (Greeen, 2012).

This model is proposed for its potential for structural interpretation, which, in our case, means modelling a latent variable through an index function: the decision to participate in 
festivities and popular celebrations. This model also allows for the adequate inclusion of qualitative variables and the identification of inputs for territorial public policies. In addition, it has an advantage over other discrete choice models such as the linear probability model (MPL) in terms of the variance term (homoscedasticity), no bounding of the estimates and no underestimation of the parameters (Espinosa, Madero, Rodriguez-Puello, \& Diaz, 2020).

For the estimation, it is controlled with individual and household variables and for the effects of the local context grouped into two types of variables: traditional and structural, the latter being a contribution of this work to the existing analysis framework. The model takes the following structure:

$$
P_{i j}=\Phi\left(x_{i j}^{T} \beta\right)=\frac{1}{\sqrt{2 \pi}} \int_{-\alpha}^{x_{i \beta}^{T}} e^{-\frac{z^{2}}{2}} d z
$$

where: $P_{i j}$ is the probability of participating of individual $i$ in any of the celebratory activities in the carnival in locality $j$ of Barranquilla; $X_{i j}$ is the vector of the explanatory variables described. For its part, the parameter vector $\beta$ represents the marginal effects of each of the explanatory variables in the participation decision, which are interpreted as probabilities.

\section{RESULTS}

\subsection{Participation in the Carnival of Barranquilla}

The Carnival of Barranquilla generates value for local society in a multidimensional way (Figure no. 1). First, its cultural value stands out, which is materialized in the feelings invoked by the attendees/participants, which are positively correlated with their personal well-being, the guarantee of rights (especially that of participating in cultural life), the development of capacities for participation and the preservation, transfer and protection of cultural heritage (dance, musical genres, musical instruments, parades, among others).

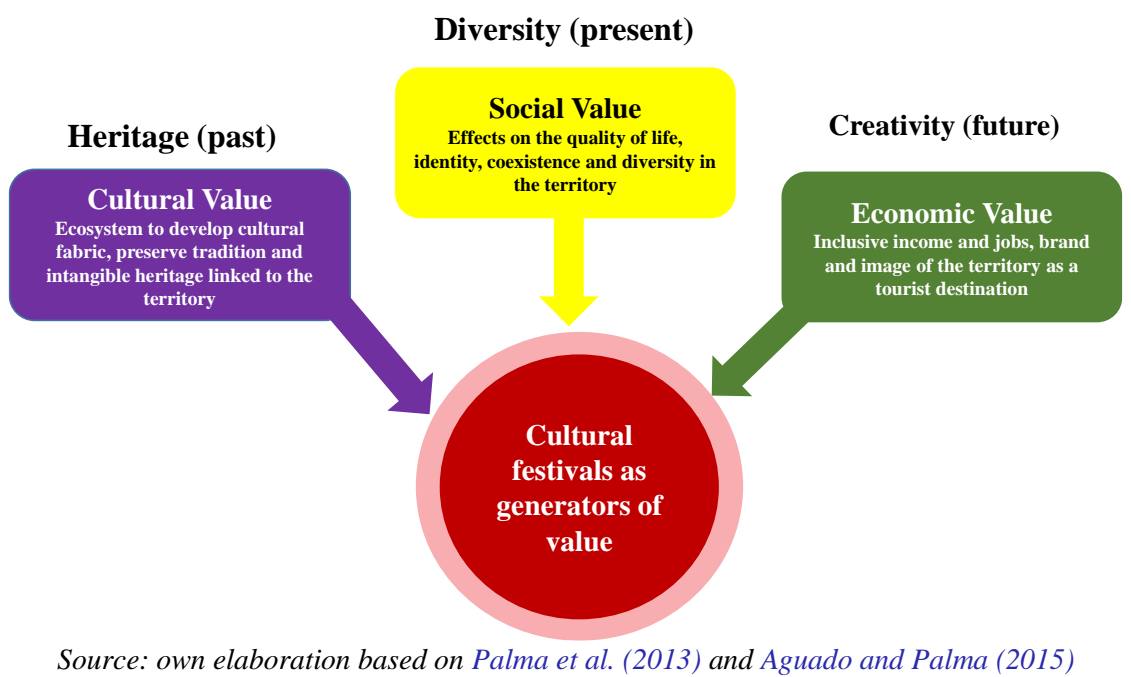

Figure no. 1 - How does a Carnival create value? The Triple Standpoint 
Towards 2008, after the national and UNESCO declarations as a Colombian cultural heritage and of humanity, there was a noticeable growth (12\% annual average) of the groups that marched in the celebrations. The dances, cumbiambas and comparsas, among other groups, went from 350 to 539, which meant an increase from 17,231 to 29,870 in the number of active participants. This same trend was experienced by the collective of makers, musicians, outfit and costume makers, and attendants, which almost doubled during the same period (they went from 11,633 in 2002 to 22,715 in 2008) (Fundesarrollo, 2008).

Second, carnivals provide social value that materializes through multiple channels, such as social cohesion, positive cultural interactions between diverse (and historically excluded) groups, and the promotion of values such as diversity and tolerance. For Salcedo, Ballesteros, Pacheco, Crawford, and Guzman (2011), carnival is not only a space for social encounters and cultural resignification but also a space for negotiation that allows a significant segment to articulate discourses and practices, a fact that makes it a "true laboratory of peace" for the population (Salcedo et al., 2011, p. 216).

Finally, its generation of economic value stands out: carnival as a source of income and jobs derived from the celebration through, on the one hand, the design, preparation and commercialization of cultural goods and services carried out by workers and local entrepreneurs and those from the area of influence of Barranquilla, and on the other hand, the increase in tourism and trade (including advertising) that boost the economy and give the territory important competitive advantages (Figure no. 1). With the celebration, gross profits calculated at US $\$ 3.5$ million were achieved in the indicated period, with the company investing approximately US \$6 million in participation through the purchase of goods and services produced by the cultural industry (Fundesarrollo, 2008).

The following analysis of participation in the carnival aims to understand these values, which focuses on describing its structure according to a set of individual characteristics of the home and its environment and on the elaboration of a profile of the attendees taking into account the type of activity they have attended and participated in. In this context, during the 12 years between 2008 and 2019, participation in the Carnival of Barranquilla reached, on average, $45 \%$ of the local population, that is, approximately 539,843 people annually (Figure no. 2).

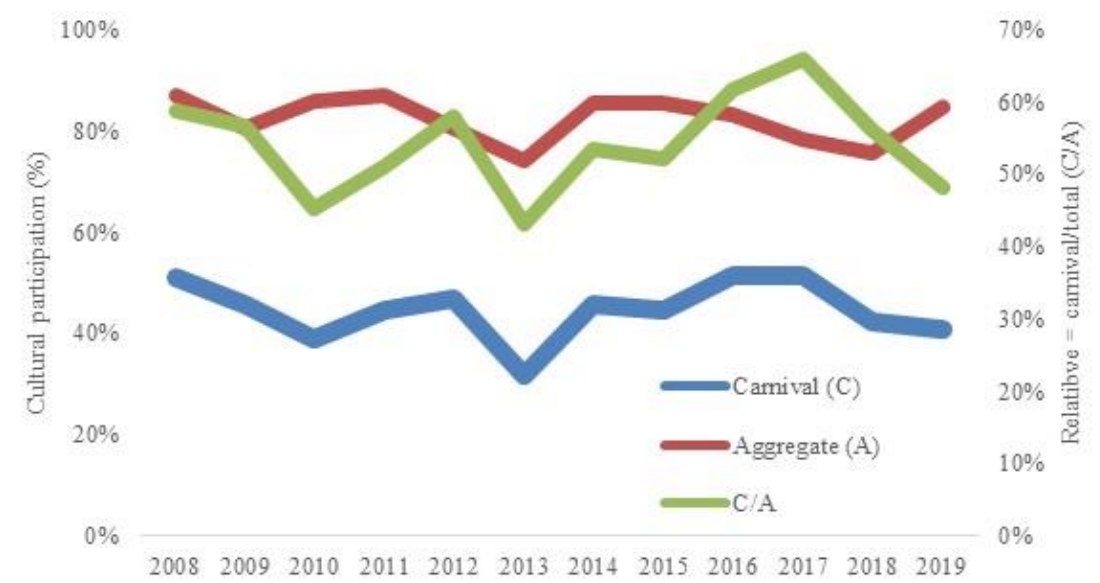

Source: own elaboration based on Citizen Perception Survey (CPS) -Barranquilla Cómo Vamos

Figure no. 2 - Participation in cultural activities and carnival, 2008-2019 
For 2011, a level of participation of $45 \%$ of the population was observed, similar to the average of the entire period analysed. When breaking down this participation, access gaps in favour of men are observed ( $46 \%$ versus $43 \%$ in women). However, these differences are much greater when measured by educational level (our proxy variable of cultural capital), age and use of free time. In effect, the local population with higher education participates in the carnival almost four times more than the illiterate (Figure no. 3); There is also a notable advantage in participation of those who study and combine work activities outside the home (Figure no. 4) and of young people, who double the participation of the older population (Figure no. 5).

Although to a lesser degree, socioeconomic status is also a source of differences in participation in the carnival activities analysed (Figure no. 6). The population located in the highest position (strata 5 and 6) shows a participation rate of $56 \%$, while the population of the lowest positions has a rate of $39 \%$. However, when compared to other cultural activities, socioeconomic status produces gaps in participation in carnival (1.4 times) lower than attendance at theatre (3.7 times), museums (2.9 times) and cinema (2.3), although similar in size to those presented in the reading of books (1.4 times).

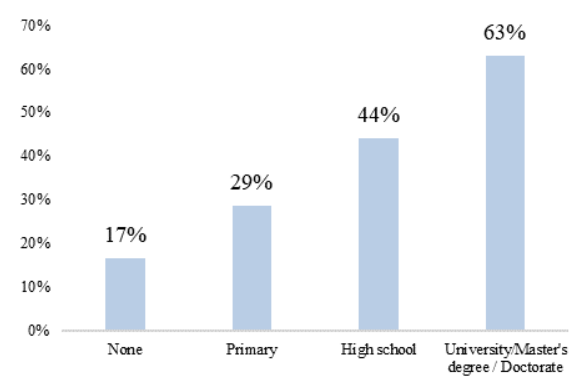

Figure no. 3 - Participation by educational level

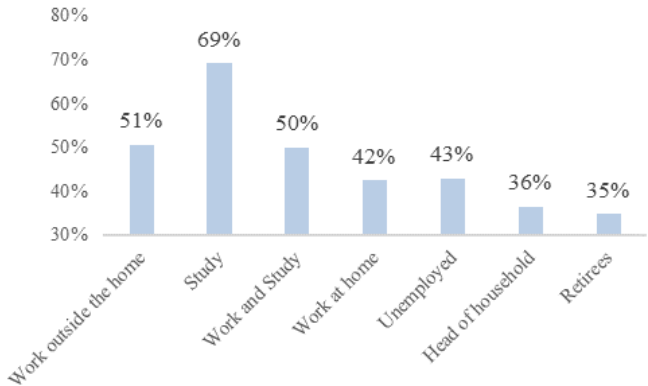

Figure no. 4 - Participation by leisure time

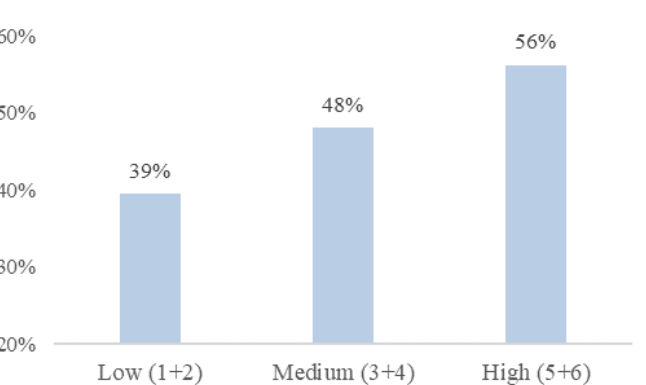

Figure no. 6 - Participation by socioeconomic status

Figure no. 5 - Participation by ag

Figure no. 6 - Participation by socioeconomic sta
Perception Survey (CPS) -Barranquilla Cómo Vamos

The previous analysis presented a profile of those who participated in the carnival according to individual characteristics, those of the home and of the environment. This profile can be complemented by establishing the differences between those who attend and do not attend the popular celebration, reviewing whether these differences are statistically relevant in the sample collected during the year of study. In other words, if differences can be attributed 
Scientific Annals of Economics and Business, 2021, Volume 68, Special Issue, pp. 79-103

to each variable with which the decision to participate or not in the carnival is theoretically related (Table no. 3 ).

Table no. 3 - Profile of participants and non-participants in the Carnival of Barranquilla

\begin{tabular}{|c|c|c|c|}
\hline & $\begin{array}{c}\text { Participants } \\
(\mathrm{N}=544)\end{array}$ & $\begin{array}{c}\text { Non-participants } \\
(\mathrm{N}=677)\end{array}$ & $\begin{array}{c}\text { Mean } \\
\text { difference tests }\end{array}$ \\
\hline Gender (Male) & 0.512 & 0.488 & $* * *$ \\
\hline \multicolumn{4}{|l|}{ Educational level } \\
\hline None & 0.025 & 0.103 & $* * *$ \\
\hline Primary & 0.062 & 0.124 & $* * *$ \\
\hline High school & 0.634 & 0.642 & \\
\hline Tertiary & 0.277 & 0.129 & $* * *$ \\
\hline \multicolumn{4}{|l|}{ Age group } \\
\hline 18-24 years & 0.233 & 0.116 & $* * *$ \\
\hline 25-34 & 0.235 & 0.155 & $* * *$ \\
\hline $35-44$ & 0.18 & 0.184 & \\
\hline $45-54$ & 0.143 & 0.178 & $*$ \\
\hline Greater than 55 & 0.207 & 0.364 & $* * *$ \\
\hline Private school & 0.297 & 0.269 & \\
\hline \multicolumn{4}{|l|}{ Leisure time } \\
\hline Works outside the home & 0.341 & 0.268 & $* * *$ \\
\hline Works at home & 0.082 & 0.09 & \\
\hline Studies & 0.123 & 0.044 & $* * *$ \\
\hline Studies and works & 0.007 & 0.005 & \\
\hline Head of the household & 0.261 & 0.366 & $* * *$ \\
\hline $\begin{array}{r}\text { Retired } \\
\end{array}$ & 0.062 & 0.094 & $* *$ \\
\hline Subjective poverty & 0.205 & 0.308 & $* * *$ \\
\hline Does not consume one of three meals & 0.126 & 0.159 & \\
\hline \multicolumn{4}{|l|}{ Socioeconomic status (stratification) } \\
\hline High $(5+6)$ & 0.139 & 0.087 & $* * *$ \\
\hline Medium (3+4) & 0.4 & 0.347 & $*$ \\
\hline Low $(1+2)$ & 0.459 & 0.565 & $* * *$ \\
\hline \multicolumn{4}{|l|}{ Better economic situation } \\
\hline Has worsened & 0.104 & 0.129 & \\
\hline Remains the same & 0.417 & 0.49 & $* *$ \\
\hline Has improved & 0.477 & 0.379 & $* * *$ \\
\hline \multicolumn{4}{|l|}{ Place of residence } \\
\hline North centre & 0.242 & 0.129 & $* * *$ \\
\hline Riomar & 0.108 & 0.134 & \\
\hline Metropolitan & 0.204 & 0.245 & $*$ \\
\hline Southwest & 0.244 & 0.258 & \\
\hline $\begin{array}{rr}\text { Southeast } \\
\end{array}$ & 0.2 & 0.231 & \\
\hline Perception of security in the city & 0.641 & 0.636 & \\
\hline Perception of security in the neighbourhood & 0.635 & 0.63 & \\
\hline \multicolumn{4}{|l|}{ Perception of quality of life } \\
\hline Satisfied & 0.841 & 0.748 & $* * *$ \\
\hline Neither satisfied nor dissatisfied & 0.106 & 0.192 & $* * *$ \\
\hline $\begin{array}{ll}\text { Dissatisfied } \\
\end{array}$ & 0.051 & 0.059 & \\
\hline Satisfaction with parks & 0.364 & 0.294 & $* *$ \\
\hline Satisfaction with the cultural offer & 0.91 & 0.74 & $* * *$ \\
\hline
\end{tabular}

Note: Level of significance of the test: * $\mathrm{p}<0.1, * * \mathrm{p}<0.05, * * * \mathrm{p}<0.01$.

Source: own elaboration based on Citizen Perception Survey (CPS) -Barranquilla Cómo Vamos 
The carnival is predominantly composed by males, with a medium and high level of cultural capital, judging by the fact that more than $90 \%$ of the attendees have a high school education or higher. It is noteworthy that almost two-thirds of the participants (63\%) had high school education, which indicates that participation in the carnival was not concentrated in the segments with greater cultural capital of the city. This result has as a counterpart the very low participation in this activity of the illiterate population $(2.5 \%)$ and with primary education $(6.2 \%)$; These are people with a low level of cultural capital and job skills and, therefore, the income required to consume this good.

From the point of view of time availability, the results tend to be consistent with the theory. In this sense, participation is related to the time constraints that people face; for example, those who work outside the home tend to participate more than those who work at home and study and work. This profile with a higher level of participation is consistent with the proxy variable of income, which increases as the perception of the economic situation improves.

Likewise, the variables provided, such as types of poverty, stratification, place of residence and perception of security, allow to show statistically significant differences in the carnival. The last traditional variable, which measures participation according to age group, also shows significant differences. The main conclusion of the analysis indicates that participation is concentrated in the two youngest and the most adult population groups.

\subsection{Results of the estimation of the probit model: the anatomy of the participant according to the frequency}

The estimates presented below are aimed at giving empirical support to the approaches of the theory according to which there is a set of traditional factors linked to models of rational addiction, learning through experience and individual characteristics (income, availability of time, cultural capital, gender and age), plus others of the local context, such as socioeconomic status, place of residence and poverty, which condition the economic and social valuation of the decision to participate in the carnival (Aguado \& Palma, 2015).

The analysis is presented for two types of participation: i) according to the frequency and ii) the type of attendance, a criterion that addresses the timeline of events that occur before and during the carnival. In the first group are occasional participants (those who attend one or two carnival events), frequent participants (attend three or four events) and regulars (more than four); people can attend several events in one or more days. The second group considers different events that happen before the carnival (Lectura del Bando, Coronation of the Queen, Gay Carnival, Children's Carnival and La Guacherna) and during its celebration, such as attendance at parades as spectators; participation in parades as a member of comparsas and folkloric groups; attendance at concerts and dances; attendance at booths, street parties and popular activities; cultural activities; and parties organized at home, by acquaintances or friends.

With this approach, two key facets of participation are covered: passive (as a spectator) and active (as a festive actor/carrier). However, following Martinell (2013) and Espinosa and Toro (2016), cultural participation is also manifested through activities that occur in public and private spaces (parades, concerts, club dances), individually and collectively, and include a wide variety of processes of expression, interpretation and creation, all of which represent forms of collective memory, tradition and contemporaneity that are materialized (or consumed) through the market or outside it (Table no. 1). 
The first estimates are presented for all participants and those occasional, frequent and regulars. In general, the models show expected results in terms of the sign of the estimated coefficients (marginal effects), the statistical significance of most of the variables considered, and the proportion of well-classified observations for the three types of participants.

For the analysis, it starts with a basic model (Model 1) that considers the key variables of the traditional approach: gender, income ${ }^{3}$, leisure time and cultural capital. To this model, other variables are added that allow to control the effect of different aspects of participation, in particular, the incidence of age (Model 2), place of residence (Model 3), socioeconomic status (Model 4) and objective and subjective poverty (Model 5) ${ }^{4}$.

The general results (aggregate, Table no. 4) show that traditional variables, especially accumulated cultural capital, play a significant role in the probability of participating in the carnival. In this case, illiteracy operates as the greatest barrier to participation, with very wide gaps compared to the reference group, the population with the highest level of education. In effect, if a person from Barranquilla is illiterate, this reduces the probability of participating by up to 41 percentage points compared to a person who reaches tertiary education (university or postgraduate).

The results are also those expected for the proxy variable of income, the perception of the economic situation, and the time available for leisure activities. For a typical inhabitant, the probability of participating in any carnival activity increases by four percentage points when their assessment of the economic situation improves.

According to the available leisure time, those who work outside the home and study increase the probability of participating if they are compared with the reference group, the heads of households. This effect is as expected and is particularly accentuated in favour of students, who increase the probability of participating by 21 percentage points compared to heads of household. Although they were not significant, the coefficients of the rest of the participants (studying and working, retired, and unemployed) show positive signs, consistent with the time-intensive nature of the carnestolendas and the time restrictions that heads of household usually face.

When control variables are added, the results show a young participant type (16 to 35 years old), who resides mainly in the North-Central Locality (where there are neighbourhoods historically linked to the celebration) and who reduces their participation when perceived as poor. As a characteristic fact, neither socioeconomic position nor gender influence the decision to participate in the carnival.

Regarding occasional participants, the marginal effect of education and the economic situation are not relevant; in the first case, because the coefficients are not significant, and in the second, because the effect is opposite to that expected, that is, it reduces the probability of participating instead of increasing it as this perception improves. However, socioeconomic status is consistent with the hypothesis according to which this variable, which reflects the stock of household wealth, positively influences participation. An aspect to consider of the occasional consumer is their age and place of residence: on the one hand, they are adults over 55 years whose probability of participating increases considerably compared to younger groups who, as observed, are the most regular participants of the carnival. On the other hand, they are more likely to be located in areas of the city other than the north-central location.

Frequent and regular participants share some common characteristics (Table no. 4, continuation). Those who participate most are young people (especially between 16 and 25 years old) and sensitive to the self-perception of poverty; however, each group shows that 
their valuation of participating is conditioned differently by other explanatory variables: in the frequent the weight of the socioeconomic status determines participation to a large extent, while in the regulars the status is not statistically significant although it presents the expected signs. Another difference lies in the type of attendees according to leisure time: the frequent attendees are largely people who work outside the home, while the regulars are mainly students and people who inhabit the neighbourhoods of the North centre locality.

In summary, the variables of the context that contribute to the traditional model differ in their explanatory character according to the participant. Socioeconomic status is relevant to explain the differences in occasional and frequent participation, although its explanatory meaning is reversed: on occasional participants, the participation of the lower strata increases in relation to the higher strata, while in the frequent participants, the wealth effect represents the highest status.

On the other hand, when controlling for the territorial location, the effect of living in the north-central location on the regulars is clear, while the marginal effect is opposite for the occasional participants. Finally, subjective poverty decreases participation in general terms, which is closely linked to the assessment of the employment situation, the levels of perceived income and the peer effect (which leads people to compare themselves with peers) as measure of the importance of relative poverty.

\subsection{Anatomy according to the type of participation}

Cultural participation is now analysed taking into account the types of events that take place within the framework of the carnival. First, with respect to cultural capital, those who most participate in pre-carnival activities (Table no. 5) are people with a high educational level, as well as those who attend as spectators to see parades, cultural activities and private parties. The greatest effect of accumulated cultural capital is observed in those who attend to observe the parades (Table no. 5).

Compared with the reference age groups, the pre-carnival events are mainly attended by workers and students, mostly young people and adults under 55 years of age, who occupy a high socioeconomic status in Barranquilla. With respect to this last variable, the results show that those who belong to strata 5 or 6 increase the probability of attending by nine percentage points compared to households of lower strata.

Due to the profile shown, the previous events allow the participation of a very diverse group from the point of view of cultural and generational capital, although with more restricted access when considering the status and available leisure time. Finally, neither the proxy variable of income nor gender was significant in explaining the decision to participate in pre-carnival activities.

On the other hand, in the attendance to the parades as spectators, the variables that condition the decision to participate are cultural capital and age. When the group over 55 years of age is taken as a reference, the probability of attendance increases for the two youngest groups, being higher for the group of 26-35 years. This group resides largely in the middle and upper strata, so it is consistent that the economic situation positively and significantly explains the decision to participate and that subjective poverty has a negative effect on this decision. In fact, these types of events usually demand time and economic resources (transport, food, among others) for their enjoyment ${ }^{5}$. 


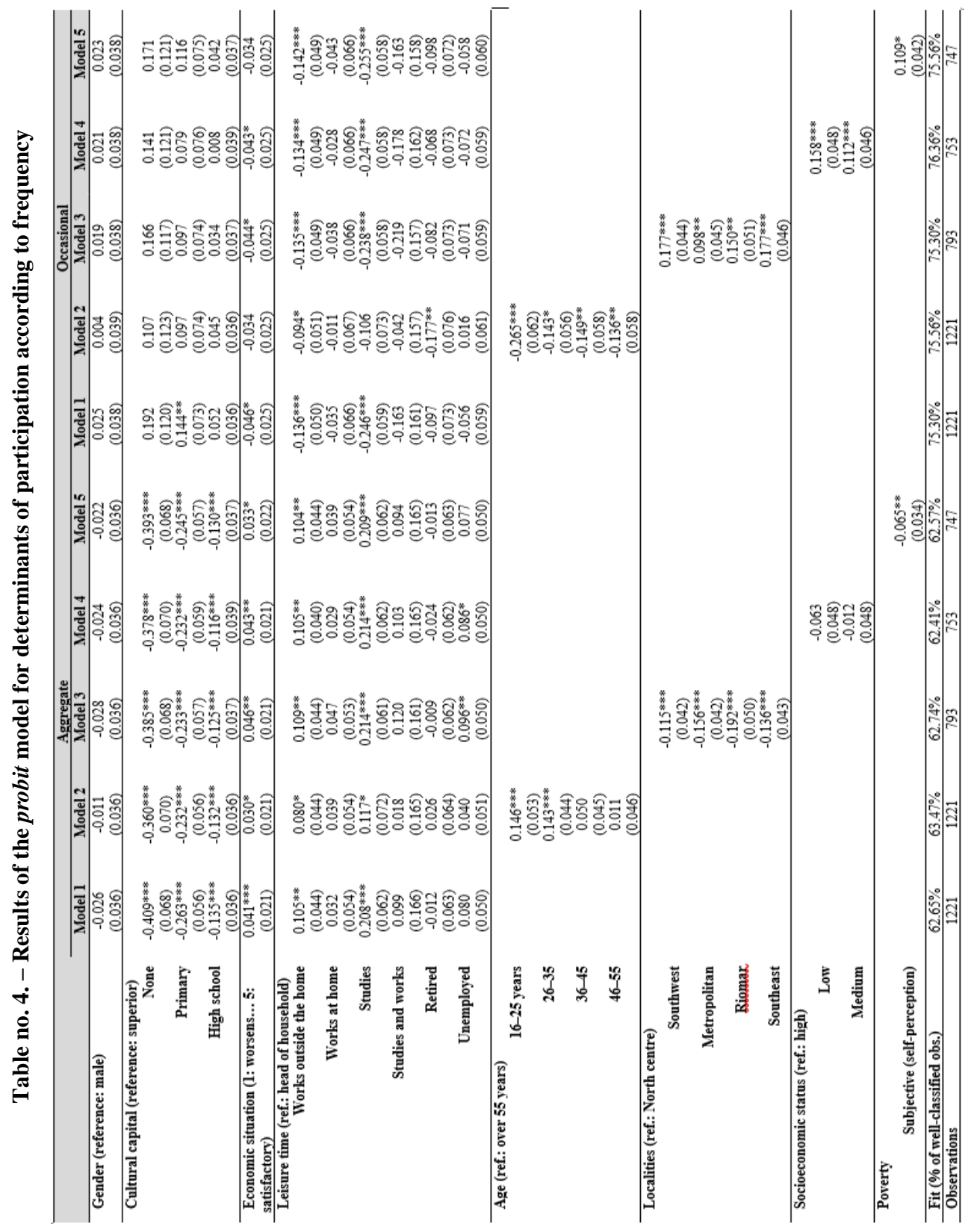

Note: ***: significant at $99 \%$; **: at $95 \%$; * at $90 \%$. Standard deviation in parentheses. Source: Own elaboration based on CPS-Barranquilla Cómo Vamos 


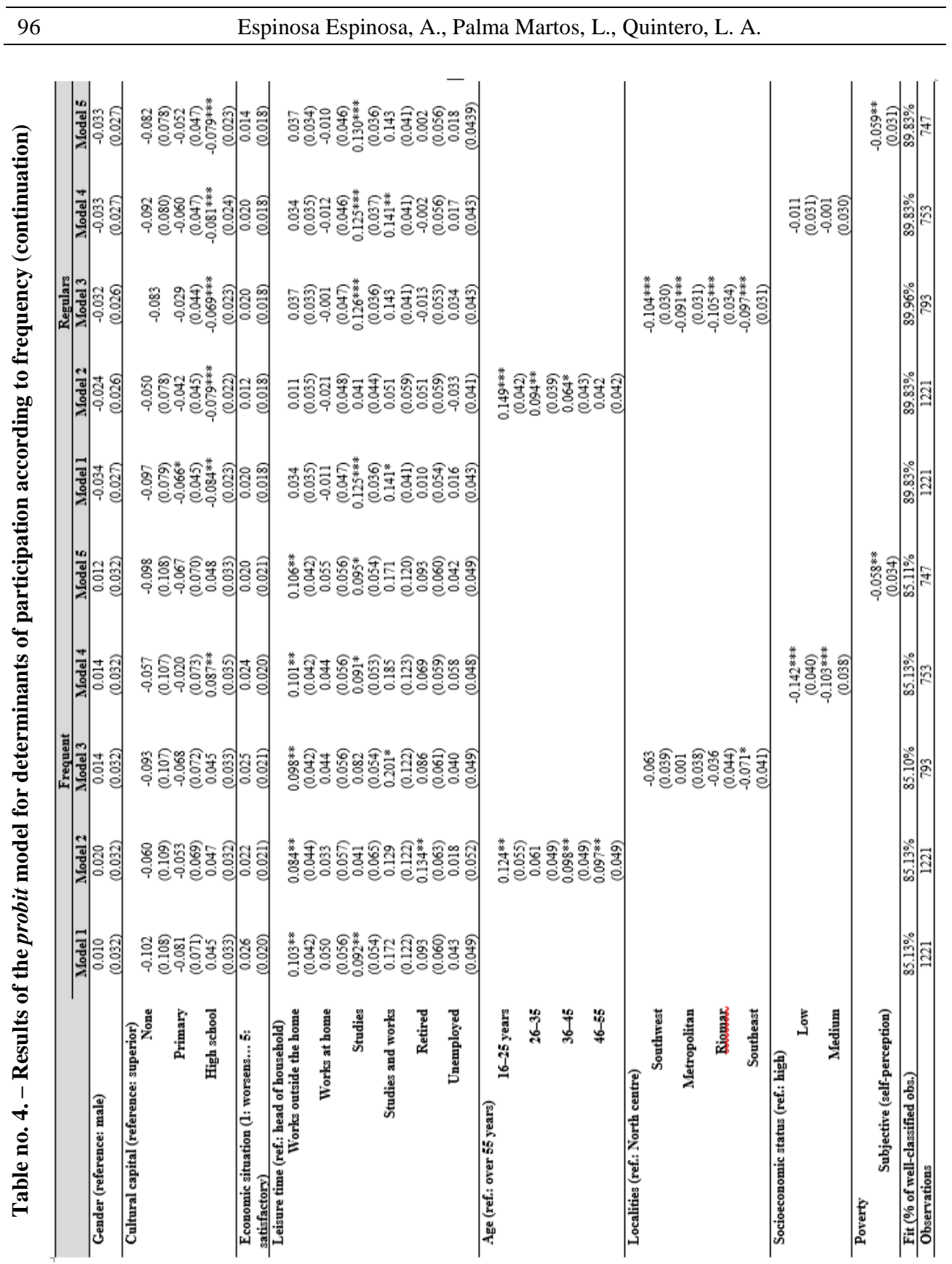

Note: ***: significant at 99\%; **: at 95\%; *: at 90\%. Standard deviation in parentheses.

Source: Own elaboration based on CPS-Barranquilla Cómo Vamos 


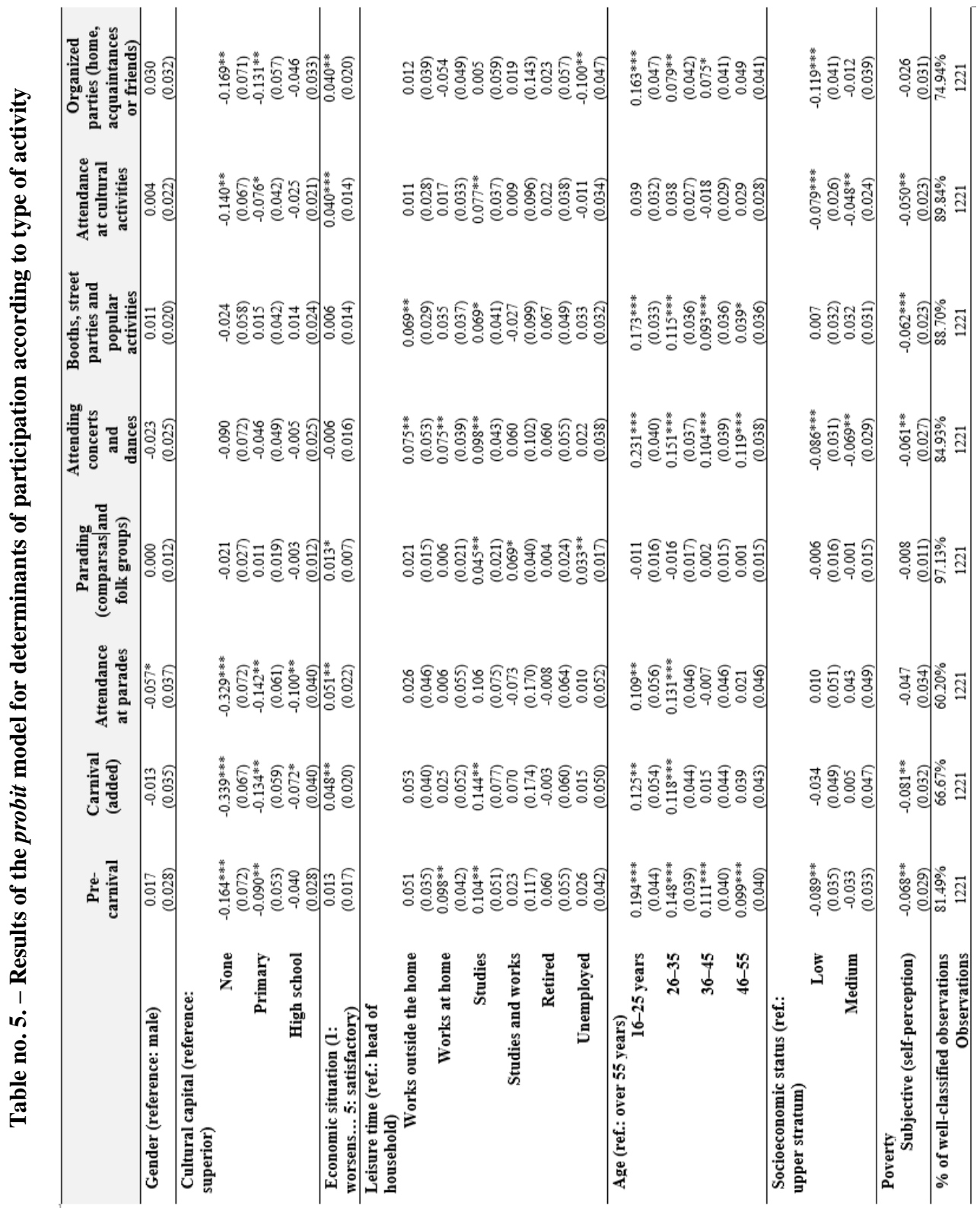

Note: ***: significant at $99 \%$; **: at $95 \%$; *: at $90 \%$. Standard deviation in parentheses. 
Because it is the counterpart of the parades, it is of interest to determine the factors associated with the decision to participate individually or as a member of comparsas and folk groups in the carnival. Due to its significance and the sign of the coefficients, the variable that best explains this decision is leisure time, especially for those who study in schools and universities, and combine studies with work. These groups, as well as the unemployed, are more likely to participate when compared to the reference group, the heads of household, who have less time than their counterparts.

Judging by the size of the marginal effects and the low significance of traditional variables such as cultural capital, gender and age and structural factors such as stratification and poverty, it can be concluded that there are no substantial differences between those who integrate these clusters. Hence, the role of bearers of tradition plays an "equalizing" role (or reducing the differences of gender, human capital and social status) in people from Barranquilla in the carnival.

Two activities that allow differentiating the profile of the participants are, on the one hand, attendance at concerts and dances and, on the other, attendance at booths, street parties and popular activities. The former are partly associated with paid events and developed within the framework of the carnival (social clubs, hotels and the like), while the latter are open to the public and traditionally take place on a broader socioeconomic basis. Although the coefficients are not statistically significant, a first difference between both participants is found in the probability of attendance of men and women. In the case of dances, women have an advantage over men in the probability of participating, while the opposite is true for attending booths and street parties.

In neither of these two activities is there evidence that the level of cultural capital is relevant to explain participation. Although the coefficients are not significant, a greater probability of participating in dances and concerts of people with higher educational level is observed, while for this same group, the probability of participating in popular festivities is reduced compared to the population with less years of education.

However, both activities involve participants with a clear work profile that is concentrated in the younger population, with this participation decreasing as age increases. Finally, socioeconomic status marks a differentiating feature of the participants in both activities: it does not explain differences between those attending open and inclusive events such as booths and street parties, as it does reflect a barrier to participation in dances and concerts, events where the willingness to pay largely defines access.

In turn, cultural capital does play a decisive role in the attendance to cultural activities that are carried out in parallel to the carnival celebration. These include exhibitions, conferences and attendance to museums, activities that require knowledge of symbolic references that allow their interpretation and appropriation.

In fact, the greater probability of attendance of those with a higher educational level demonstrates the specific weight of the cultivation of taste in the formation of the preferences of these consumers. Although there is no evidence to affirm that there are differences in participation attributable to gender, age or time use, the weight of socioeconomic status and subjective poverty as markers of attendance is clear.

Finally, parties organized at home or by friends show a pattern marked by a high level of cultural capital. These celebrations are concentrated in the youngest and most working population and constitute a strongly stratified activity for the participants. 


\section{CONCLUSIONS AND DISCUSSION}

In this study, cultural participation in the most representative popular feast in Colombia, the Carnival of Barranquilla, was analysed. The analysis allowed to take an approach from the cultural economics, aimed at understanding the role of its traditional determinants and the local context, using an information base and an empirical strategy that can be replicated to other carnivals and popular festivities in Colombia and Latin America.

The analysis carried out allowed the construction of the differentiated profile of the carnival participant, taking into account the intensity and type of activity carried out. The empirical evaluation allowed to obtain results consistent with the nature of a cultural asset such as carnival, a time-intensive cultural activity with strong social interactions in its consumption.

A first conclusion allows to verify the particularity of this centennial celebration compared to popular festivities and festivals of a similar nature documented by the empirical literature. Unlike events such as the Spring Fiestas of Seville (Palma et al., 2013) and the American rodeo (Daneshvary et al., 1993), it was possible to demonstrate the importance of traditional variables (in particular, cultural capital and income) to explain the decision to participate in the carnival.

For Palma et al. (2013), cultural capital does not determine participation in Sevillian festivities, and this is due to "[...] intrinsic characteristics of this asset as it is more closely linked to intangible heritage and, therefore, to the popular culture" (Palma et al., 2013, p. 101). However, the findings for the carnival show that the educational level explains not only part of the differences in appropriation of this feast but also the possible links of greater cultural capital with the availability of resources for participation.

In the case of income, whose analysis was approached from the perception of the economic situation, its usefulness to explain the differences in the types of participation (passive or active) more clearly than when it is used to study the frequency of participation, is shown. This result is consistent with the differences found by Daneshvary et al. (1993) between the type of tournament (national, regional or local) and the frequency of participation.

An additional conclusion allows the identification of gaps in participation according to the set of characteristics analysed. In the carnival, the gaps are mainly associated with age, general cultural capital level, economic situation (proxy variable of income), time available for leisure, and others as contributed to analysing the local context, such as subjective poverty, the location of the household and socioeconomic status. These last results suggest that participation in the carnival is stratified and, given the distribution of the population (Cepeda, 2014), is concentrated in certain areas of the territory. The stratification is greater the lower the frequency, and the events require resources for access to scheduled activities.

By emphasizing the use of time of each person according to their different roles, the results allow to differentiate the role of the opportunity costs faced by the participants. According to the results, the youngest groups that use their time to study and work at the same time are those who most participate in popular festivities such as carnivals. If the connections between these types of participants and the traditional variables of rational addiction models are addressed, participation is maximized when the acquired cultural capital and the resources derived from a stable work condition are connected.

Likewise, the study allowed to identify the role of subjective variables in participation. This demonstrates the weight of circumstantial factors other than the economic situation that, on the one hand, condition the social and economic evaluation of attendance and, on the other hand, provide insights to understand the sources of satisfaction of people with their living environments. 
Within the framework of a cultural policy that encourages participation, it was found that its management goes beyond the scope of intervention of the carnival organizers. These are structural factors, a result of the process of urban formation and growth, which operate as barriers to the enjoyment and appropriation of this heritage asset.

Access opportunities are restricted according to differences in deprivation (objective poverty) and the environment of households (status and location). However, the organizers of the carnival together with the local government can influence by expanding the offer to communities that lack resources and opportunities to access this festivity and decentralizing the events to the areas of the territory to reduce the existing gaps.

\title{
Acknowledgements
}

The authors specially thank to Observatorio del Caribe Colombiano for supporting this research. Also to Gabriel Rodríguez Puello (Universidad Tecnológica de Bolívar) and Ignacio Martínez Fernández (Universidad de Sevilla) for their valuable comments, and to Tatiana Caly Amador for her helpful support in the construction of the database. We also thank the comments by Carlos Chavarría Ortiz (Escuela Universitaria de Osuna) in the Workshop on Economics and Management of Popular Culture, organized by the Escuela Universitaria de Osuna (University School of Osuna), the Universidad de Sevilla (University of Seville) and the Pontificia Universidad Javeriana (Pontifical Xavierian University) (June 23-24, 2021).

\section{ORCID}

\author{
Aaron Espinosa Espinosa (iD https://orcid.org/0000-0001-8805-4166 \\ Luis Palma Martos (iD https://orcid.org/0000-0001-5834-3629 \\ Luis Aguado Quintero iD https://orcid.org/0000-0002-1675-0418
}

\section{References}

Abello, J. (2020). Un tesoro atravesado por multiples tensiones. In Jaime Bonet M. \& Javier Pérez V. (Eds.), 20 años de estudios sobre el Caribe colombiano (pp. 543-553): Colección de Economía Regional, Banco de la República. http://dx.doi.org/10.32468/Ebook.664-409-9

Abello, M., Buelvas, M., \& Caballero, A. (2005). Tres culturas en el Carnaval de Barranquilla. Revista Huellas Vol. 71-72-73-74-75. Barranquilla (Colombia): Eds. Uninorte.

Aguado, L. (2011). Análisis empírico del comportamiento del consumidor de artes escénicas en Colombia. (PhD), Departamento de Economía e Historia Económica, Universidad de Sevilla, Sevilla.

Aguado, L., \& Palma, L. (2015). Factores que limitan la participacion cultural. Una mirada desde la economia de la cultura. Revista de Ciencias Sociales, XXI(1), 58-71.

Andrade, D. (2016). Determinantes de la asistencia a museos en Colombia. Una perspectiva desde la economía de la cultura. (PhD), Departamento de Economía e Historia Económica, Universidad de Sevilla, Sevilla.

Ateca-Amestoy, V. (2008). Determining heterogeneous behavior for theater attendance. Journal of Cultural Economics, 32(2), 127-151. http://dx.doi.org/10.1007/s10824-008-9065-z

Ateca-Amestoy, V. (2009). El capital humano como determinante del consumo cultural. Estudios de Economia Aplicada, 27(1), 87-110.

Ateca-Amestoy, V. (2010). Cultural participation patterns: Evidence from the Spanish time use survey. Paper presented at the ESA Research Network Sociology of Culture Midterm Conference: Culture and the Making of Worlds. https://ssrn.com/abstract=1692024 
Baumol, W., \& Bowen, W. G. (1966). Performing Arts: The Economic Dilemma: A study of problems common to theater, opera, music, and dance: Twentieth Century Fund.

Becker, G. (1965). A Theory of the Allocation of Time. The Economic Journal, 75(299), 493-517. http://dx.doi.org/10.2307/2228949

Becker, G., \& Murphy, K. (1988). A Theory of Rational Addiction. Journal of Political Economy, 96(4), 675-700. http://dx.doi.org/10.1086/261558

Bermúdez, J., Medina, L., \& Aguado, L. (2016). La decisión de escuchar música grabada en Colombia. Un enfoque microeconométrico. Revista de Métodos Cuantitativos para la Economía y la Empresa, 21-38.

Borgonovi, F. (2004). Performing arts attendance: An economic approach. Applied Economics, 36(17), 1871-1885. http://dx.doi.org/10.1080/0003684042000264010

Buelvas, M. (1993). El Carnaval de Barranquilla, una filosofia del carnaval o un carnaval de filosofias. Revista Huellas, 39, 5-12.

Buelvas, M. (2005). El Carnaval de Barranquilla. Una filosofía del carnaval o un carnaval de filosofías (Vol. 71-72-73-74-75). Barranquilla: Eds. Uninorte.

Buelvas, M. (2011). Asi es el carnaval Carnaval de Barranquilla. Fiesta sin fin (pp. 87-110). Barranquilla: Fundacion Carnaval de Barranquilla.

Cámara de Comercio de Barranquilla, \& Carnaval de Barranquilla SAS. (2017). Impacto económico del Carnaval de Barranquilla. Retrieved from https://www.camarabaq.org.co/carnaval-de-barranquilla-sa/

Carbó, G. (1993). Al ritmo de... tambora-tambora Revista Huellas (pp. 27-58). Barranquilla (Colombia): Eds. Uninorte.

Casarin, F., \& Moretti, A. (2011). An international review of cultural consumption research. Department of Management, Universita Ca' Foscari Venezia Working Paper, 12. http://dx.doi.org/10.2139/ssrn.2037466

Cepeda, L. (2014). Los sures de Barranquilla: la distribucion espacial de la pobreza. In L. Cepeda (Ed.), La economia de Barranquilla a comienzos del siglo XXI (pp. 1-40): Banco de la Republica.

Daneshvary, N., Schwer, R., \& Rickman, D. (1993). Determinants of demand for professional rodeo attendance. Journal of Cultural Economics, 17(2), 77-92. http://dx.doi.org/10.1007/BF02310584

de Friedemann, N. S. (1984). Perfiles sociales del Carnaval de Barranquilla. Revista Montalban, 15.

Espinosa, A., Madero, M., Rodriguez-Puello, G., \& Diaz, L. (2020). Etnicidad, espacio y desarrollo humano en comunidades pobres urbanas: La comuna 6 en Cartagena de Indias, Colombia. Cuadernos de Economia (Santiago, Chile), 39(81), 635-666. http://dx.doi.org/10.15446/cuad.econ.v39n81.77333

Espinosa, A., \& Palma, L. (2019). Cultural Participation in the Main Colombian cities, 2008-2015. Scientific Annals of Economics and Business, 66(Special issue - dedicated to the VIII Wo), 37-58. http://dx.doi.org/10.47743/saeb-2019-0021

Espinosa, A., Palma, L., \& Aguado, L. (2020). A micro-econometric approach to participation in a cultural festival. The case of Carnival of Barranquilla (Colombia). Paper presented at the IV Gijon Conference on the Economics of Leisure, Culture and Sport.

Espinosa, A., \& Seni, G. (2019). Las letanias del carnaval de Barranquilla: entre lo sacro y Lo pagano. Isotopias e intersubjetividades recurrentes. Metafora. Revista de literatura y analisis del discurso, 2. http://dx.doi.org/10.35286/mrlad.v1i2.18

Espinosa, A., \& Toro, D. (2016). La participacion en la vida cultural en Cartagena, 2008-2013. Economía\&Región, 10(1), 217-248.

Falk, M., \& Katz-Gerro, T. (2016). Cultural participation in Europe: Can we identify common determinants? Journal of Cultural Economics, 40(2), 127-162. http://dx.doi.org/10.1007/s10824015-9242-9

Fernández-Blanco, V., \& Prieto-Rodríguez, J. (2009). Analisis de los habitos de lectura como una decision economica. Estudios de Economia Aplicada, 27(1), 87-110.

Fundesarrollo. (2008). Carnaval de Barranquilla. Impacto económico local. [inédito].

Gilard, J. (1999). La reine du carnaval. Barranquilla 1959. Caravelle, 73, 147-167. http://dx.doi.org/10.3406/carav.1999.2858 
González, A. (2006). Danza, mestizaje y carnaval. Un fenomeno latinoamericano: el caso de Barranquilla. In E. Gutierrez \& J. Edgar (Eds.), Fiestas y carnavales en Colombia. La puesta en escena de las identidades (pp. 43-58). Cartagena (Colombia): La Carreta Editores.

González Pérez, M. (2018). La Fiesta en Colombia. Albores del siglo XXI. Estudios Artísticos, 5(6), 60 71. http://dx.doi.org/10.14483/25009311.14103

Greeen, W. (2012). Econometric Analisys (7th ed.). New York: Pearson.

Gutiérrez, E. (2009). Fiesta de La Candelaria en Cartagena de Indias. Creer, poder y gozar: Universidad de Cartagena e Instituto de Patrimonio y Cultura de Cartagena.

Heredia-Carroza, J., Palma, L., \& Marín, A. (2020). Determinants of attendance frequency to flamenco shows in Spain. A cultural economic approach. Revista de Métodos Cuantitativos para la Economía y la Empresa, 29, 79-98. http://dx.doi.org/10.46661/revmetodoscuanteconempresa.3751

Lévy-Garboua, L., \& Montmarquette, C. (1996). A microeconometric study of theater demand. Journal of Cultural Economics, 20, 25-50. http://dx.doi.org/10.1007/s10824-005-5050-y

Lizcano, M., \& Gonzalez, D. (2007). Documentales sobre el Carnaval de Barranquilla: Una historia audiovisual. Boletín de Antropología de la Universidad de Antuiquia, 38, 357-380.

Mariano, M., \& Endere, M. (2017). Carnavales y patrimonios: diálogos sobre identidades y espacios de participación. Memorias: Revista Digital de Arqueología e Historia desde el Caribe, 13(32), 10-41. http://dx.doi.org/10.14482/memor.32.10338

Martinell, A. (2013). Derechos culturales y desarrollo: una propuesta de análisis de sus impactos. In A. Martinell (Ed.), Impactos de la dimensión cultural del desarrollo. Girona: Universidad de Girona y Universidad Tecnológica de Bolívar.

Mauri, C. A., \& Wolf, A. F. (2021). Battle of the ballet household decisions on arts consumption. Journal of Cultural Economics, 45, 359-383. http://dx.doi.org/10.1007/s10824-020-09395-z

McCain, R. (2003). Taste formation. In R. Towse (Ed.), A Handbook of Cultural Economics (pp. 445-450): Edward Elgar Publishing. http://dx.doi.org/10.4337/9781781008003.00062

McFadden, D. (1973). Conditional logit analysis of qualitative choice behavior. In P. Zarembka (Ed.), Frontiers in Econometrics (pp. 105-142): Academic Press.

Montoro-Pons, J., Cuadrado-Garcia, M., \& Casasus-Estelles, T. (2013). Analysing the Popular Music Audience: Determinants of Participation and Frequency of Attendance. International Journal of Music Business Research, 2(1), 35-62.

Muñoz, E. (2007). Cartagena festiva. El 11 de noviembre y sus signos culturales. Colombia: Corporacion Concurso Nacional de Belleza.

Observatorio del Caribe Colombiano. (2015). Ministerio de Cultura and Alcaldia de Barranquilla. Colombia: Plan Especial de Salvaguardia del Carnaval de Barranquilla.

Ochoa, F. (2015). La cumbia en el carnaval de Barranquilla: construccion de un metarrelato. Revista Encuentros. http://dx.doi.org/10.15665/re.v15i3.1097

Palma, M., Aguado, L., \& Osorio, A. (2014). Determinants of Book Reading and Library Attendance in Colombia. A microeconometric approach. Economics and Business Letters, 3(2), 79-86. http://dx.doi.org/10.17811/ebl.3.2.2014.79-86

Palma, M., Palma, L., \& Aguado, L. (2013). Determinants of cultural and popular celebration attendance: The case study of Seville Spring Fiestas. Journal of Cultural Economics, 37(1), 37-87. http://dx.doi.org/10.1007/s10824-012-9167-5

Pérez, G. J., \& Salazar Mejía, I. (2008). La pobreza en Cartagena: un analisis por barrios. In A. M. Roca (Ed.), La economia y el capital humano de Cartagena de Indias (pp. 9-49). Cartagena: Centro de Estudios Economicos Regionales, Banco de la Republica.

Rey Sinning, E. (2004). Joselito carnaval. Análisis del Carnaval de Barranquilla (5th ed.). Bogotá: Plaza y Janés, Editores Colombia S.A.

Reyes, V. (2011). Tiempo anómico: El carnaval de Barranquilla. Revista Colombiana de Sociología, 34(1), 103-126.

Ringstad, V., \& Loyland, K. (2006). The demand for books estimated by means of consumer survey data. Journal of Cultural Economics, 30(2), 141-155. http://dx.doi.org/10.1007/s10824-006-9006-7 
Scientific Annals of Economics and Business, 2021, Volume 68, Special Issue, pp. 79-103

Ruz, G., \& Abello, A. (2016). Las Fiestas de Independencia como patrimonio cultural inmaterial de la Nación colombiana. Serie de Documentos Encuentros, 1(2).

Salcedo, L. (2002). Carnaval de Barranquilla. Obra Maestra del Patrimonio Oral e Intangible de la Humanidad. Barranquilla (Colombia): Ministerio de Cultura de Colombia.

Salcedo, L., Ballesteros, H., Pacheco, C., Crawford, L., \& Guzman, B. (2011). Carnaval, la industria cultural que se toma una ciudad. In Fundacion Carnaval de Barranquilla (Ed.), Carnaval de Barranquilla. Fiesta sin fin (pp. 215-225). Barranquilla (Colombia): Fundacion Carnaval de Barranquilla.

Seaman, B. A. (2006). Empirical Studies for Demand in the Performing Arts. In V. A. Ginsburgh \& D. Throsby (Eds.), Handbook of the Economics of Art and Culture (pp. 415-472). Amsterdam: Elsevier.

Stigler, G., \& Becker, G. (1977). De gustibus non est disputandum. The American Economic Review, 67(2), 76-90.

Throsby, D. (2001). Economics and culture. Cambridge (UK): Cambridge University Press.

Throsby, D. (2003). Cultural capital. In R. Towse (Ed.), Handbook of Cultural Economics (pp. 166-169). USA: Edward Elgar Publishing Ltd. Cheltenham.

Throsby, D. (2006). Handbook of the Economics of Art and Culture (Vol. 1): Elsevier. http://dx.doi.org/10.1016/S1574-0676(06)01001-5

Verbeek, M., \& Vella, F. (2005). Estimating Dynamic Models from Repeated Cross-Sections. Journal of Econometrics, 127, 83-102. http://dx.doi.org/10.1016/j.jeconom.2004.06.004

Villarroya, A., \& Escardibul, J. O. (2010). La demanda de libros y publicaciones periodicas en Espana. Estudios de Economia Aplicada, 28(1), 1-22.

\section{Notes}

${ }^{1}$ The municipalities that make up its metropolitan area (Puerto Colombia and Soledad) are not included since no information is available on these throughout the period analysed.

${ }^{2}$ This was initially conceived as a classification mechanism for residential properties used by the State for the allocation of utility rates, as well as for targeting of social programs (Pérez \& Salazar Mejía, 2008).

${ }^{3}$ For 2011 this variable is not included in the CPS of Barranquilla Cómo Vamos; for this reason, we resort to a proxy variable, the perception about the economic situation, which, in theory, captures the effect of income variations on the decision to participate in cultural activities.

${ }^{4}$ Other variables of the context were not significant, these are: social capital, security and the type of education of children and young people.

${ }^{5}$ It should be noted that objective poverty measured as lack of food was used for both the estimate according to frequency and the estimate according to each type of event. The results, in relation to the rest of the explanatory variables, which exclude the self-perception of poverty, show corner case for occasional participants and attendees of cultural activities, dances and concerts, and popular street parties and booths. Reading these results is simple: in an extreme situation such as the one measured by the variable, people decide not to participate.

\section{Copyright}

This article is an open access article distributed under the terms and conditions of the Creative Commons Attribution-NonCommercial-NoDerivatives 4.0 International License. 